International Journal of English Literature and Social Sciences
Vol-6, Issue-5; Sep-Oct, 2021

Peer-Reviewed Journal

\title{
Revisiting T.S. Eliot's The waste land in light of Contemporary Society
}

\author{
Prakash Philip
}

Choottuvelil (H), Veliyannoor (P.O), Kottayam, Kerala, India

Received: 08 Aug 2021; Received in revised form: 11 Sep 2021; Accepted: 17 Sep 2021; Available online: 22 Sep 2021

C2021 The Author(s). Published by Infogain Publication. This is an open access article under the CC BY license

(https://creativecommons.org/licenses/by/4.0/).

\begin{abstract}
Human Civilization has gone through many stages of drastic changes to be in the present form. Some were productive, while others were catastrophic. But still, humans as a species survived and flourished on the surface of the earth. But the story doesn't end here. In this process of change, there are many hurdles to be crossed. One such hurdle is the advent of diseases which soon took shape of a pandemic. History witnessed many such pandemic with heavy casualties. A pandemic of recent origin is COVID-19, which has caused the whole world into a standstill and creates many cracks in many sectors of society. This research aims to find out the various clues regarding this outbreak in decades old poem The Waste Land by T.S.Eliot.
\end{abstract}

Keywords - The Waste Land, Pandemic, Eco-criticism.

\section{INTRODUCTION}

Human beings and their encounter with natural calamities and pandemics are not new. Thus, the recordings of all these calamities are obvious. Likewise, many of these disasters are referred to in many works of literature and some of them even become well-known works in literature. The pandemic situation keeps everyone at home. So, people are more connected through online. Many virtual chat rooms appeared to help us connect with each other. But there is also the aspect of online fatigue which can't be ignored. At this point, books come to our help. Many books have references to these kinds of pandemics and even some works were formed as a result of a pandemic.

The Waste Land by T.S. Eliot is one such poem that depicts the consequences of this pandemic long ago. The impact of the First World War and its after-effects must give the poet an impulse to compose this poem. Much of the poetry of The Waste Land was achieved in the search of finding apt symbols for an experience that cannot be told. These symbols were later deciphered with the passage of time. Thus, The Waste Land is regarded as an important social document. The poem also studies as a self-expression of an age of emotional sterility and haunted by fear. His presentation of the 'Unreal City' is very powerful, showing the sense of spiritual emptiness which led to fear and hysteria. And these factors are intensified in society with the outbreak of COVID-19 pandemic.

\subsection{Objective}

The aim of this research is to describe the aspects related to COVID-19 in the poem by a careful analysis of the work. Through exploring these pandemic-related aspects, it was also able to find out the social and individual repercussions due to the pandemic and the solution to these grave problems. The research also delves into another crucial aspect, Eco-criticism, which is the process of criticizing anthropogenic activities to the Nature, which is a hot topic. A careful examination of the poem and the exploration of those elements are depicted here.

\subsection{Methodology}

The advent of pandemic opened the eyes of society towards some facts like the value of family, the difficulty of being inside a confined space for long and the consequences of exploiting nature for one's whims and fancies. In this respect, this research based on a narrative 
review provides an overview of the content available on a given topic.

\section{REREADING THE WASTE LAND DURING PANDEMIC}

The Waste Land which is regarded as an extremely difficult poem, but was also a great positive achievement and it lead to a poetic triumph out of the difficulties that confronted a poet of that age. The impact of the First World War and its after-effects must give the poet an impulse to compose this poem. Much of the poetry of The Waste Land was achieved in the search of finding apt symbols for an experience that cannot be told. These symbols were later deciphered with the passage of time. Thus, The Waste Land is regarded as an important social document. The poem also studies as a self-expression of an age of emotional sterility and haunted by fear. His presentation of the 'Unreal City' is very powerful, showing the sense of spiritual emptiness which led to fear and hysteria. And these factors are intensified in society with the outbreak of COVID-19 pandemic. The various sections of The Waste Land got hidden clues that depict the times decades ahead of its composition. A careful examination of the poem and the exploration of those elements are depicted here.

The title of the first section of The Waste Land itself raise eyebrows in readers when it is analyzed at the backdrop of the pandemic. The first section originally emphasizes the inevitable dissolution due to First World War and calls the people to lead a new life, it dubiously narrates today's world gulped by a tiny organism.

April is the cruelest month, breeding

Lilacs out of the dead land, mixing

Memory and desire

These are the opening lines of the poem. In the poem, it's a part of an interior monologue by the protagonist, Tiresias. April becomes literally the cruelest month as it was the beginning of a nation-wide lockdown which leads to the confinement of people inside their homes across the world. Another part is the breeding of lilacs. Lilacs grow in the spring season. These lilacs now mix the memories of the golden past and the desires for things that one wanted to do. Thus it creates despair in the minds of people who are confined by the four walls of their home, which is contrary to what it intends to do.

Summer surprised us, coming over the

Starnbergersee

With a shower of rain: we stopped to the

colonnade
Hofgarten

And went on in sunlight, into the

And drank coffee, and talked for an hour

These lines show an anecdote in the poet's life. It may not seem significant for an ordinary reader. But when one examines the poem on a pandemic background, it could be observed that the poet here shows what's inside the minds of people in present. During lockdown, people got themselves into the memories of wandering outside and enjoying Nature. Thus, these lines show the inner thoughts of people years after its composition which reminds the readers of the mysteries hidden in the poem.

What are the roots that clutch, what branches grow

Out of this stony rubbish? Son of man,

You cannot say, or guess, for you know

only

A heap of broken images, where the sun

beats

And the dead tree gives no shelter, the cricket no relief,

And the dry stone no sound of water.

Only

There is shadow under this red rock,

(Come in under the shadow of this red

rock),

from either

And I will show you something different

Your shadow at morning striding behind

you

meet you;

Or your shadow at evening rising to

I will show you fear in a handful of dust.

Here, Tiresias asks himself what roots can hold firmly the materialistic life of man.

What branches grow out of this stony rubbish?

This line has a relevance to the present society. Metaphorically, the "stony rubbish"denotes the dilapidated society and "branches"denote hope. So, in the modern sense, Tiresias is asking whether any hope would come during these times. The voice of today's desperate people is seen in this age-old verse.

Here the poet denotes people as the "Son of Man" which shows how much the people have distanced themselves from God. It also refers that man fallsprey to the materialistic and consumerist forces of the society. His 
belief in materialism is not helping him overcome the crisis. The poet here mocks the modern society. "A heap of broken images" are the images of shattered society. "Dead tree" is not giving him shade and the cricket gives him no relief (the "cricket" here represents Mother Nature).

\section{There is shadow under this red rock}

Tiresias advises men to come under the shelter of Christianity. The shadow of Christianity is peaceful and comfortable. The shadow of materialism chases him in the morning and enters only in the evening. It is ironic in the sense that the shadow is supposed to provide relief to men. But, this shadow is doing the exact opposite even though it is following him throughout the day. But under the shadow of Christianity, he sees the shadow of Christ walking beside him to protect from all kinds of suffering.

This shows the importance of faith in human lives. When people go through sufferings, it's the faith that this struggle will end soon and the hope for a brighter future is what moves the people forward. The pandemic has once again, showed the need of faith and what hope really means.

\section{I will show you fear in a handful of dust.}

Here, "handful of dust" shows mortality. It's a reminder that whatever feats one strives to accomplish, the end result being the same: death. The inevitable fact of humanity once again underlines in this line.

\section{Unreal City,}

Under the brown fog of a winter dawn,

A crowd flowed over London Bridge, so

many,

I had not thought death had undone so

many.

exhaled,

Sighs, short and infrequent, were

And each man fixed his eyes before his

feet.

Tiresias is depicting London city for the first time in the poem. The city is under the brown fog. Fog symbolizes materialism. It shows how materialistic forces control all aspects of society. Materialism has frozen the minds of people that they are short of all virtues. This is exactly what is happening in the modern society. Sighing people denotes the barrenness they have inside. Each person is lost in thoughts of his own well-being and had his eyes fixed before his feet. The dry nature of human mind is what is represented here.

The second part of the poem, "A Game of Chess"denotes sex has become an intrigue, a source of momentary pleasure. But hidden in these lines are the depictions of people who are locked away in the cage of quarantine due to pandemic.

The Chair she sat in, like a burnished

throne,

fruited vines

Glowed on the marble, where the glass

Held up by standards wrought with

From which a golden Cupidon peeped

out

(Another hid his eyes behind his wing)

Doubled the flames of sevenbranched

candelabra

Reflecting light upon the table as

The glitter of her jewels rose to meet it,

Opening section of this part portrays an elaborate description of the luxury of a mansion. Living luxuriously is truly a dream-come-true moment for most of the people. But what they forget is that the luxury never fulfills anything enduring. It will only take away the peace of mind. Eliot employs the use of luxury to show his readers that despite all the pomp, and power, people got bored and eventually got fed up with the meaningless routine of life. This void got deeper during the pandemic.

The modern woman in the poem views her life as a "Game of Chess" in which she plays with caution to keep her husband under her power. But that makes her life emptier.

Stay with me.

'My nerves are bad to night. Yes, bad.

Speak to me. Why do you never speak.

Speak

thinking? What?

What are you thinking of? What

I never know what you are thinking.

Think'

All the meaningless luxury and her desperate attempts to control her husband made her neurotic and hysterical. A reader can use these lines to show the misery of people trapped in lockdown.

\section{Stay with me. Speak to me}

This line anchor itself to the minds of readers. The woman in the poem is literally begging her husband to chat. During lockdown, all the members of the family are together, yet their relationship is meager. Modern technology actually keeps people on their own fortresses like 'Thorin who refused to come out of the Lonely 
Mountain in Dale' in the novel "The Hobbit" (The Hobbit).

\section{I think we are in rat's alley}

Where the dead man lost their bones

In these lines, Tiresias refers to Mrs. Equitone's room where she sat in her chair. She said to the visitor that she's nervous. She wants the visitor to stay with her and speak. The visitor kept quiet. She got annoyed and asked what he was thinking. The visitor replies that all the people are living in a narrow street in which the spiritually dead live and die. Here the people are all rats who are troubled by worldly affairs. The street (may represent the materialistic life) is where the people have lost their bones.

The emptiness is what vividly represented through these lines. People in pandemic are isolated from everything and they are living with fear whether they survive or not. It has battered both the body and soul of a person.

'What shall I do now? What shall I do?

I shall rush out as I am, and walk the

street

With my hair down, so. What shall we do

tomorrow?

\section{What shall we ever do?'}

It shows the fact that the people, who have been locked down for a long time, have become hysterical. Long days of isolation affect the mental state of most of the people during the pandemic. Eliot never would have thought that the words he used to describe the post-war society would become the reality years after. It also shows the importance of being a part of a family. Only with joint efforts that people could sail this ship of hope in the sea of despair.

Studies have shown how mental health of people was affected. On a report published by a preprint server "medRxiv" in May 2020 shows

"...high levels of depression among front line healthcare workers and people in communities with high infection rates. Such anticipatory stress and anxiety, along with loneliness, could not only affect mental health but lead to a decline in lifestyle quality and, ultimately, one's health choices" (How India's lockdown has affected mental health).

White bodies naked on the low damp ground

And bones cast in a little low dry garret,
The above lines are from the third section of The Waste Land titled "The Fire Sermon".It shows the corruption and degradation of humanity and the downgrading of sexual pleasures. Sex is now a mere business proposition or for immediate pleasure. Not only sex has vulgarized and commercialized, there also prevail abnormal sexual practices. The relevance of these lines to our present situation is very obvious.

The mass burials in New York in Hart Island are the point where the fiction becomes the reality. The report states that

"...it is not clear how many of the dead have no next-of-kin or could not afford a funeral. However, the city has cut the amount of time it will hold unclaimed remains amid pressure on morgue space"(Coronavirus: New York ramps up mass burials amid outbreak).

Coming to the final section of the poem, "What the Thunder Said", the theme discussed in this section is "life-in-death". It suggests the living death of the inhabitants of The Waste Land. It is evident that that man lost his faith in God and it resulted in the loss of vitalityboth spiritually and emotionally. During this pandemic, this sterility turns out to be the final nail of the coffin. With no support from materialistic forces and no faith, both men and society looks bewildered and they have no clue regarding the future. There are corpses all over and people are trying to "survive" and forget about "living". No shadow is there to provide relief to people in this desert of sorrow and devastation. In this modern desolate land, people exist like dead things. Life has now becomes a series of complete inactivity and apathy.

\section{He who was living is now dead \\ We who were living are now dying \\ With a little patience}

What the speaker talks about is Christ. Christ is no longer alive in this modern world. It shows that humanity who got enriched by this symbolic concept, no longer responds to them. The loss of faith in God made the human lives spiritually dry. There is no sense of redemption in people's eyes during pandemic. These lines could also be interpreted in another way. It may refer to the time between the death of Christ and His resurrectionthe time of waiting and suffering by which the term patience implies. This gives us a ray of hope that what's after this pandemic is a world of joy and comfort.

Here is no water but only rock

Rock and no water and the sandy road 
The road winding above among the

mountains

Which are mountains of rock without

water

Here Tiresias refers to Christian love as water. It is the God's love for mankind. He tells that this land is devoid of water and there's only rock of materialism. The roads are sandy because the land has turned into a desert. It contains some religious views, but when one looks closely, it can be observed that this scene metaphorically reveals the inner turmoil of people during pandemic. From the valleys of mere fiction, it goes to the mountains of materialistic philosophy in search of answers. But these are arduous rocks for human souls. They provide nothing, irrespective of man's efforts. The poet here says that the end result of all materialistic philosophies is void. Its relevance is established during the pandemic. People are null and void in soul now days. No money or worldly comforts offer them asylum.

mountains

There is not even silence in the

\section{But dry sterile thunder without rain}

There is not even solitude in the

mountains

\section{But red sullen faces sneer and snarl \\ From doors of mudcracked houses}

The poet states that the materialist looks upon spiritual pursuits as futile and does not believe in the independent existence of Soul, God, Heaven or Hell. Tiresias says that mind of materialistic man is full of mountains of worldly ambitions and sensual desires in which there is no mental peace or silence. Mental sky is covered with clouds of anxiety, fear of poverty, accident and so on. The clouds are dry and unfruitful. That is, they are imaginings with empty thunders. They always shatter the peace of the place. Materialist looks out of their mudcracken houses and express contempt for red sullen faces of unfulfilled desires. The people are not ready to mend their ways even in the wake of pandemic. They still wish to be trapped in the giant web of materialism and consumerism for comfort and peace. But the more they look into it, the more they lose it. Twenty-first century societal trend is explained in Twentieth-century poem.

$$
\text { I do not know whether a man or a }
$$

woman

-But who is that on the other side of you?

Tiresias feels tortured by dry sterile thunder. As he struggles forward, his nervous exhaustion fancies a vision of a third figure and he does not know whether it is a man or a woman. As a general trend, it can be interpreted as the hysterical experiences of men who are confined to a prescribed place for a consecutive time period. Or, in other sense, it can be said that the other person may be the COVID-19 virus. Here the "virus" is personified and indicates the present time in the poem. People, during the tough times of pandemic, are always surrounded by a virus and it follows everywhere. Or, in other words, people are always accompanied by death. There is no security to people's lives during pandemic. Wherever one goes, death follows.

\section{Falling towers \\ Jerusalem Athens Alexandria \\ Vienna London \\ Unreal}

This shows the fall of all cities and civilizations before the virus. "Falling towers"could symbolically signify how the tower of falsehood and materialism falls before the virus. The list of the towns is part of a long list of civilizations that are falling before pandemic. It becomes more astonishing that Eliot was able to prophesy the future in his poem.

what have we given?

My friend, blood shaking my heart

surrender

The awful daring of a moment's

\section{(aviender}

retract

Which an age of prudence can never

By this, and this only, we have existed

obituaries

Which is not to be found in our

Or in memories draped by the
beneficent spider

Or under seals broken by the lean solicitor

\section{In our empty rooms}

Here the poem is moving to the Indian mythical background in search of an answer for the spiritual and emotional barrenness. It's not the thunder that speaks but the Supreme Lord of Creation, answering to His creations. The first $D A$ is about acceptance, not refusal. People locked in isolation can only escape by self-surrender and sympathy with others. It also shows another trait of modern man, selfishness.

Society becomes more selfish by looting from the weak whatever they want, ignoring the lives of the affected. Now the pandemic has made them think otherwise. Surrendering means that people should learn to 
live with the virus, which is what most of the countries are trying to do. Adapting to the environment is the key to ensure the continuity of humanity. It is through brotherhood and sympathy that people would be able to move forward. Among all the other things, these facts create hope to the future, a society learning to co-operate and sympathize with others by sharing the resources.

\section{I have heard the key}

Turn in the door once and turn once only

We think of the key, each in his prison

Thinking of the key, each confirms a

prison

After surrender, Tiresias heard the key turn in his prison. It's a moral that an individual locked in his solitary identity can escape from it only through self-surrender and sympathy with others. This is a life lesson that was reminded during the pandemic. Society has witnessed that how much people would help each other and what all wonders could be done if people unite irrespective of all societal barriers.

\section{Shall I at least set my lands in order?}

London Bridge is falling down falling down falling down

The speaker wishes to set his own house in order though everything in society is crumbling down. The whole civilizational structure is crumbling, yet the speaker is trying to mend his own life. This gives a simple, yet powerful lesson; that salvation should come from within. Only by reforming yourself that you could reform society as family constitute the basic element of society. Also, falling down.

London Bridge is falling down falling down

This linedenotes all civilizations ever formed and still existing on the surface of Earth. Eliot shows how our actions led to our own fall. It is known to everyone that the changing lifestyles and increase of emission of greenhouse gases and the resultant global warming give birth to new types of diseases.

A research made by Osong Public Health and Research Perspectives shows that Global Warming induces considerable impact on human health. The result states that

"....climate change has altered the distribution of some infectious disease vectors, the seasonal distribution of some allergenic pollen species, and increased heat wave related deaths" (The Effect of Global warming on Infectious Diseases).
The concepts of Datta, Damyatha and Dayadhvam have great relevance during these perilous times. "Give" to those who need it, "Sympathize" on others plight and take "Control" of what you can do to make the society better. The re-reading of The Waste Land on various societal aspects that makes Thomas Sterns Eliot a prophet and the poem "an epic".

\section{ECO-CRITICISM IN THE WASTE LAND}

T.S Eliot's use of literary experimentation within an urban context represents a major innovation in nature writing that modernizes eco criticism and makes it relevant to the realities of modern life. The depiction of urban and rural landscapes in the poem demonstrates a clear development in Eliot's environmental consciousness and provides vital insights into modern anxieties regarding the changing relationship of human beings to nature. Study of Eliot's work from a green approach reveals a number of environmental issues and a sustained commitment to environment by his similar explorations of anthropology, psychology, and literary experimentalismand urban places. T.S. Eliot's poetry shows a clear interest and comparison in the natural world and nineteenthcenturyenvironmental issues. As a survivor of two world wars and keen observer of the rise of modernity in Western society, herecognized a destructive change in the relationship between humans and nonhuman living things.

'The Waste Land'itself conveys in it the simple standardof eco-basic examinations.Looking at Eliot from an eco-critical point of view not just creates new bits of knowledge into the writer's work, yet additionally holds different advantages for the theory of ecocriticism. The poet was aware ofthis notion and therefore he found a metaphor and a parable of nature to highlight the human degradation of thecontemporary world. The title gains support as loss of spirituality and decadence of nature both results in thehuman downfall. It was this striking similarity between spirituality and nature which might have motivated thepoet to choose the title of the poem as The Waste Land.Eliot's poetry offers a study of the natural effect of ecocriticism. Modernity emphasizes the physical, psychological and artistic importance of cultivating a close relationship with the natural world.

Poem represents alienationbetween the human psyche and the rest of the natural world as well.The opening lines of 'The Burial of the Dead' portray defilement of nature through its loss of raising a point of confinement and corruption of human nearness through its loss of extraordinary quality. The poet has integrated the theme of modern man's spiritual hollowness with nature's 
loss of vitality.In Eliot's verse, water symbolizes both life and passing. Eliot's characters stay nearby for the water to fulfill their thirst, watch streams surge their banks, cry for the rain to satisfy the dry earth, and sit by spoiledpools of standing water. Slighting the way that water has the regenerative probability of re-establishing life andriches, it can moreover incite the feeling of suffocation and passing, likePhlebas the sailor from The Waste Land.

\section{April is the cruelest month, breeding}

Lilacs out of the dead land, mixing

Memory and desire, stirring

Dull roots with spring rain.

Winter kept us warm, covering

Earth in forgetful snow, feeding

A little life with dried tubers.

Elliot describes a dismal atmosphere where roots and branches cannot grow, the trees are dead and there's no water flowing into the streams. Generally, spring has been viewed as a positive event in life, when nature wakesup from winter's sleep. In modernist literary composition, April, the month once spring takes full hold, is termedas the "cruelest month." One reason is that April is the time of Easter that is the time of the death of Christ. Thedead tree provides no shelter is associated with the conditions which are frightful and unfit to measure. Theauthor conjointly mentions death and alternative synonyms of death and decay as dead land, dull rootsanddried tubers are pictured. There's no life in this atmosphere and the reader sense the dark tone of thespeaker.

".... The poet profusely uses the images of dry stone, dull roots, dried tubes, sandy road, mountain rocks without water etc. which have got a double function. First they symbolize man's spiritual sterility and secondly they paint the modern ecological wasteland which is no more a place that instills a sense of confidence and hope in its inhabitants" (Titus pp .69).

What are the roots that clutch, what branches grow

Out of this stony rubbish? Son of man,

You cannot say, or guess, for you know

only

A heap of broken images, where the sun

beats,

And the dead tree gives no shelter, the cricket no relief,

And the dry stone no sound of water.
Here the speaker is in a query to find something that might help them in this land, he is looking for a stream in this vast desert of spiritual and physical sterility. Man's whole conception of himself is now nothing more than " $a$ heap of broken images". This has got more than a spiritual and cultural context. It's a reminder for the people to look into the devastated land that they live. The limitless technological advancements have been given a nickname 'development'. But people remain in total oblivion about the end result of this mindless intrusion upon environment. What do people really gained by cutting trees and poisoning the surroundings? Is it not actually retrogression if people view things by taking the future also into consideration? There is no answer since the development only provides the world with a "heap of broken images". The speaker is actually showing the world the end result of the exploitation to the environment:

\section{I will show you fear in a handful of dust}

It shows the ultimate answer for all the humans in the world. That humans and the society they build will wither and perish. Eliot's description of modern city and its inherent chaos, sickness and unlivable environment should also be examined in this poem. The poem shows an intricate image of a city that grows out of proportion and the readers, along with the crowd in the poem, get no escape from its spell. Just as modern man has got no freedom from modern cities which enslave his physical, mental and emotional life, the readers too cannot escape from the horrific spell of modern city. Eliot describes the city as unreal. There are no other words which could aptly show its brutalizing monotony. Cities will always grow, expand and develop. But there should be something out there to keep the growth in check. The people who are now living in these cities have almost lost all vitality and life giving forces. The sense of community life has been lost and the inhabitants are under the brutal mechanistic culture of the modern civilization.

Unreal City,

Under the brown fog of a winter dawn,

A crowd flowed over London Bridge, so many,

I had not thought death had undone so many.

Sighs, short and infrequent were exhaled

And each man fixed his eyes before his feet.

Flowed up the hill and down King William Street, 
To where Saint Mary Woolnoth kept the

hours

With a dead sound on the final stroke of nine.

These lines show the spirit of modern age that now dominates humanity with the advent of industrialism and man's complete surrender to modern science and technology. The expansion of city drew great number of people from far-off villages that had to serve their immemorial links with their rural settings. Their life in city has transformed them into mere machines; people flowing over the London Bridge serve as a testimony to this harsh reality. Jobs that they are engaged got nothing to offer them in terms of inner nourishment and harmony.

In the second section "A Game of Chess", the speaker of the poem derides the how modern world has lost in touch with nature. The organic life-giving nature has turned into inorganic lifeless objects.

The Chair she sat in, like a burnished

throne,

Glowed on the marble, where the glass

Held up by standards wrought with

fruited vines

From which a golden Cupidon peeped

out

(Another hid his eyes behind his wing)

Doubled the flames of svenbranched

candelabra

Reflecting light upon the table as

The glitter of her jewels rose to meet it,

From satin cases poured in rich

profusion.

The description of the first lady in this section shows how much people need to change. The everincreasing craze of men to rejoice in luxury and his efforts are exactly the reason what turn humanity into a cancer to the very planet in which humans inhabit. People try to be more isolated from his surroundings.

In the fifth part, What the Thunder Said, Eliot presents the decay of modern Europe. In The Waste Land Eliot forges a link between nature and the material world. Although the poem deals with war's physical and emotional effects, the speaker of the poem uses drought as a symbol of death. The typist who appears in this section is bored and tired of the new urban life that has forced her to fit into a life pattern of not her choice and aptitude. The fire and water that should work as purification, leading to renewed vigor, becomeimages empty of any potentially real transformation of the psyche: the burning sun merely desiccates the soul.

The river's tent is broken; the last

fingers of leaf

Clutch and sink into the wet bank. The

wind

Crosses the brown land, unheard. The

nymphs are

\section{Departed.}

Sweet Thames, run softly, till I end my

song.

The river bears no empty bottles, sandwich papers,

Silk handkerchiefs, cardboard boxes

cigarette ends

The nymphs are

Or other testimony of summer nights.

\section{Departed.}

These are the opening lines in the third section. The speaker, Tiresias is sitting on the banks of river Thames. The bank contains remnants of a camp that took a night before. Tiresias is walking through the remnants. He is sad about the gangling nature of the river. On the first note, these lines may consider as a lament of a person to a river. But, from an eco-critical point of view, these lines are considered as a warning that shows the degradation of Mother Nature. The section opens on the banks of a river. It can be traced from the history of all civilizations that organized life begins on the banks of rivers and lakes. By putting the Thames as background, Eliot shows the imminent destruction of civilizations. The ragged picture of river shows that.

Tiresias is the prophet capable of walking the perennial "Wasteland" of civilization withoutbeing defeated by its propensity for doom. He is the master of paradox, the blind man whosees more than any other, who reveals Oedipus's greatness as his downfall and warns thatthe king's talent - for solving puzzles like that of the Sphinx - would also prove his misery, as

it does at the culmination of the Theban tragedy. What Tiresias sees becomes the substance of the poem.

I Tiresias, though blind, throbbing between two lives,

Old man with wrinkled female breasts, can see

At the violet hour, the evening hour that strives 
Homeward, and brings the sailor home from sea,

Eliot's seer is a dual gendered creature of the dusk that inhabits a liminal space, whereritual converses with the powers beyond the rational, auguring danger as well asregeneration from the gaps between (or beyond) the signs that make up conventional discourse. Tiresias represents a meltdown in differentiations between night and day,inhabiting the twilight between worlds, as well as the night itself.This points us towards the regenerative forces beyond merehuman powers, beyond the lifelessness of the cultural desert of daylight rationality, into thedarkness that is not lack but womb and relief.

The river sweats

Oil and tar

The barges drift

With the turning tide

The oil spills that took place on the water sources are not to be treated lightly. It results in serious environmental hazards which leads to serious ecological risk and long term environmental disturbances.

On a report released by the chemical society of Nigeria, oil spill may cause;

".....result in the alteration of the food chain and eventually leads to the death and emigration of many organisms, hence destructing the ecosystem" (Nasar and Martin pp.68).

The fourth section titledDeath by Water doesn't need a close analysis to seek the environmental impacts it portrays. This section is a short one, depicts the drowning of Phonecian sailor in water. Water considered as source for purification and regeneration. But here, water is a symbol of destruction.

\section{A current under sea}

Picked his bones in whispers. As he rose

and fell

He passed the stages of his age and

youth

\section{Entering the whirlpool.}

The life of Phonecian sailor was always revolved in business and money. But they didn't provide any help when he needed the most. It never had any spiritual motivation. So there is no rebirth for him. In the same way, modern people who are indulged themselves in money-making are devoid of any spiritual pleasures. Nothing in it could provide any peace of mind. Thus the lives of people in the cities are doomed without any spiritual rebirth. If we look this from an ecological point of view, it depicts the alarming rate of increase of sea length and the subsequent destructions made due to flood or tsunami.

A study made by National Geographic revealed that

“...Average sea levels have swelled over 8 inches (about $23 \mathrm{~cm}$ ) since 1880, with about three of those inches gained in the last 25 years. Every year, the sea rises another .13 inches $(3.2 \mathrm{~mm})$ " (Sea level rise, explained).

The final section, What the Thunder said gives a way for people to make changes.

Which are mountains of rock without

water

drink

If there were water we should stop and Amongst the rock one cannot stop or

think

Sweat is dry and feet are in the sand

If there were only water amongst the

rock

In the poem, the explorers are in search of Holy Grail. In an ecological sense, the poem shows the near future of self-centered society. The destruction of the environment will soon make resources scarce. People looking for water will not be a rare sight in the coming days. Another fact to be noted here is that these problems were evident even in the first-quarter of twentieth century. Eliot had the perception that future would be unlivable on the physical, psychological and emotional plane if the society chooses the dangerous path of blind materialism.

cracked earth

$$
\text { Over endless plains, stumbling in }
$$

\section{Ringed by the flat horizon only}

What is the city over the mountains

Cracks and reforms and bursts in the

violent air

\section{Falling towers \\ Jerusalem Athens Alexandria \\ Vienna London \\ Unreal}

Here, people are stumbling into the narrow opening in the earth. Then Tiresias sees a vision of a city. The city may be Jerusalem, Athens, Alexandria, Vienna or London. Suddenly the mountain on which the city is situated makes a violent sound, bursts into bluish air and 
its towers are seen falling. The cracking of ground and the falling of cities are more than metaphorical. It shows the upcoming future of all human civilizations. Urbanization so often works toalienate its populace from the non-human world, while the individual is imagined by Eliot tobe locked inside the body as if this were a form of punishment.Ecological issues, social issues concerning the earth are increasing at a fast pace and the state of mind of people towards nature is becoming more and more fragile, thus denying a future. On the other hand, these lines show how these natural phenomena's are interrelated to environment. All things in this planet are interrelated. So, one can't deny the possibility of the occurring of natural phenomenon at the cost of increasing global temperature.

A paper released by The Guardian states that

"....It has been known for some time that rainfall also influences the pattern of earthquake activity in the Himalayas, where the 2015 Nepal earthquake took close to 9,000 lives, and where the threat of future devastating quakes is very high. During the summer monsoon season, prodigious quantities of rain soak into the lowlands of the Indo-Gangetic plain, immediately to the south of the mountain range, which then slowly drains away over the next few months. This annual rainwater loading and unloading of the crust is mirrored by the level of earthquake activity, which is significantly lower during the summer months than during the winter" (How climate change triggers earthquakes, tsunamis and volcanoes).

The only way to escape from such a horrifying future is to listen to the message of the thunder: Datta, Damyata, Dayadhvam. Poet through these lines says that what people want is not only to control passions, but also to a control the desire for material progress. So it is high time that people should get readjusted the life style towards this ideal. If people ignore this and the present pace of devastation continues, all of humanity will sit, like the protagonist and brood.

\section{I sat upon the shore}

Fishing, with the arid plain behind me

Shall I at least set my lands in order?

The alienation of men from its nature is obviously what makes the ecological condition worse.

We think of the key, each in his prison

Thinking of the key, each confirms a

prison
These lines identify the mind as a form of incarceration and it indicates the way that the modern men in general senseare alienated fromthe rest of nature.

London Bridge is falling down falling down falling down

The cities around the world, with its traditional forces of fertility are struggling to survive the devastating consequences of technological society. The poem's arid world of shattered and scattered images conveys the fragmentedstate of the urbanized soul as well as its desacralizedenvironment.The Waste Land succeeds in displaying modernity's failure, existing bothwithin the psyche and without it, in the world, illuminating the existential dilemma of twentieth-century life as well as anticipating the ecological crisis casting theshadows of doom, endangering the very project of urban civilization itself.

\section{CONCLUSION}

T.S. Eliot's 'The Waste Land' is perhaps the most studied, poked, prodded, dissected poem of the century. And there is no doubt that one's enjoyment of it may be enhanced by knowing the wide range of literary and mythic sources that Eliot drew upon. It is Eliot's social criticism and its contemporary relevance that highlights this study.it throws light on the decay of the present world and the answer to all the problems humans face. Eliot is one of the few writers who could imbibe the modern sensibility in the right and true perspective.

Eliot's description of the past and its aspects along with a modern sensibility helped him perceive present society. His awareness of social responsibilities as a poet was a significant factor responsible for his artistic and intellectual development. This project aims to examine this aspect after a critical analysis of his views in society and how it resembles the reality. The poem The Waste Land is analyzed for its focus on issues like societal imbalance, mindless materialism, ecological ravages, effect of pandemic on society and its consequences. Along with the theme of perils of urbanization and degeneracy of modern society, Eliot hid the upcoming dangers in futures in the symbols present in the poem. A closer analysis of the poem helps to reveal those factors and helps to find out the immortality of such great works in literature. The rich lady with neurosis in the second section A Game of Chess shows the present plight of people during lockdown. The falling of cities before the pandemic and the solution to the curse of pandemic too is entrusted in the poem.

The rapid urbanization and industrialization resulted in concomitant social and ecological disasters. 
The ruthless and mindless exploitation of nature leads to the withering away of those humane qualities in people which helped them in the past. The spiritual, material and emotional lives of people are affected by this. Eliot foresaw this a long time ago and was able to give an artistic representation through The Waste Land. The poem helps readers to wake up and to brood upon the scourge men makes from time to time for their own ultimate doom. But Eliot here does not put the blame on man's complete surrender to modern age and technology.

\section{ACKNOWLEDGEMENTS}

Author is thankful to the Department of English Literature of Mar Augusthinose College, Ramapuram under the chairmanship of Dr. Joy Jacob and Head of the Department, Prof. Jobin. P. Mathew. Author is especially grateful to Dr. T.K. Titus, an esteemed scholar who helped in many ways to formulate the ideas into research.

\section{REFERENCES}

[1] "Coronavirus: New York ramps up mass burials amid outbreak". BBC NEWS, BBC, 10 April 2020, https://www.bbc.com/news/world-us- canada52241221. 29 May 2021.

[2] "How climate change triggers earthquakes, tsunamis and volcanoes". The Guardian For 200 years, Guardian News \& Media Limited, 16 October 2016,

https://www.theguardian.com/world/2016/oct/16/climat e-change- triggers-earthquakes-tsunamis-volcanoes. 20 June 2021.

[3] "How India's lockdown has affected mental health". NEWS-MEDICAL LIFE SCIENCES, News-Medical.Net, 27 May 2020, $\underline{\text { https://www.news- }}$ medical.net/news/20200527/How-Indias-lockdown- hasaffected-mental-health.aspx. 29 May 2021.

[4] Nasar and Martin. "Likely Long Term Effects" ENVIRONMENTAL IMPACTS OF MARINE OIL SPILL; A CASE STUDY OF DEEP WATER HORIZON OIL SPILL AT THE GULF OF MEXICO UNITED STATE OF AMERICA 2010 (A REVIEW). Volume 3 (2) ISSN: 2276707X, December 2012, pp. 6.

[5] "Sea level rise, explained". NATIONAL GEOGRAPHIC, 1996-2015 National Geographic Society, 19 February 2019 ,

https://api.nationalgeographic.com/distribution/public/a mp/environme nt/article/sea-level-rise-1.19 June 2021.

[6] "The Effect of Global warming on Infectious Diseases". Osong Public Health and Research Perspectives, Elsevier B.V, 14 October 2010, https://www.ncbi.nlm.nih.gov/pmc/articles/PMC37668 91/. 30 May 2021.

[7] "The Hobbit".Wikipedia, the free encyclopedia, Wikimedia Foundation, 28 May 2021,
https://en.m.wikipedia.org/wiki/The_Hobbit. 09 June 2021.

[8] Titus, T.K. “A CRITICAL STUDY OF T.S. ELIOT'S WORKS. edition 1, ATLANTIC PUBLISHERS AND DISTRIBUTORS, 1999. 